\title{
The meiofauna as neglected carriers of antibiotic resistant and pathogenic bacteria in freshwater ecosystems
}

\author{
Maria Belen Sathicq, ${ }^{\S}$ Tomasa Sbaffi, ${ }^{\S}$ Giulia Borgomaneiro, Andrea Di Cesare, Raffaella Sabatino* \\ National Research Council, Water Research Institute, MEG Molecular Ecology Group, Largo Tonolli 50, 28922 Verbania, Italy \\ $\S$ These authors contributed equally to this work.
}

\begin{abstract}
The World Health Organization considers antibiotic resistance as one of the main threats to human and other animals' health. Despite the measures used to limit the spread of antibiotic resistance, the efforts made are not enough to tackle this problem. Thus, it has become important to understand how bacteria acquire and transmit antibiotic resistant genes (ARGs), in particular in the environment, given the close connection between the latter and human and animal health, as defined by the One-Health concept. Aquatic ecosystems are often strongly impacted by anthropogenic activities, making them a source for ARGs and antibiotic resistant bacteria (ARB). Although freshwater meiofauna have been the object of active research, few studies have focused on the relationship between the spread of antibiotic resistance and these organisms. In this review, we investigated freshwater meiofauna as carriers of resistances since they play a central role in the aquatic environments and can harbor human and animal potential pathogens. We assessed if these animals could contribute to the spread of ARGs and of potentially pathogenic bacteria. Only four taxa (Rotifera, Chironomidae, Cladocera, Copepoda) were found to be the subject of studies focused on antibiotic resistance. The studies we analyzed, although with some limitations, demonstrated that ARGs and ARB can be found in these animals, and several of them showed the presence of potentially pathogenic bacteria for humans and animals within their microbiome. Thus, meiofauna can be considered a source and a reservoir, even if neglected, of ARGs and ARB for the freshwater environments. However, further studies are needed to evaluate the impact of the meiofauna on the spread and persistence of antibiotic resistance in these ecosystems.
\end{abstract}

\section{INTRODUCTION}

The development and spread of antibiotic resistance are emerging threats to human and animal health, due to the overuse and misuse of antibiotics in human healthcare and animal farming in the previous decades (MacLean and Millan, 2019). Urgent actions are needed to tackle the spread of antibiotic resistance and avoid the "worst case scenario" of 10 million dead people/year by 2050 because of antibiotic resistant bacterial infections (de Kraker et al., 2016), as estimated by O'Neill in 2014. It is becoming clearer that the measures adopted until now to limit the spread of resistances are insufficient. It is essential to face this challenge using wider approaches, which focus on the role of the environment as a reservoir of antibiotic resist-

Corresponding author: raffaella.sabatino@irsa.cnr.it

Key words: Antimicrobial resistance; aquatic environment; benthos; pathogens; plankton.

Received: 8 August 2021.

Accepted: 22 November 2021.

This work is licensed under a Creative Commons Attribution NonCommercial 4.0 License (CC BY-NC 4.0).

${ }^{\circ}$ Copyright: the Author(s), 2021

Licensee PAGEPress, Italy

J. Limnol., 2021; 80(3):2054

DOI: 10.4081/jlimnol.2021.2054 ance (Finley et al., 2013) and apply the One-Health principles (Guardabassi et al., 2020). The One-Health concept considers the health of humans closely connected to and dependent on that of other animals and the environment (Robinson et al., 2016). To fulfill these criteria, it is pivotal to consider all the possible biotic and abiotic factors favoring the spread of the antibiotic resistance and all the ecological niches where the resistances can develop and persist in the environment (Finley et al., 2013). Thus, investigating the characteristics and the dynamics of the antibiotic resistance genes (ARGs) and of the bacteria that harbor them (antibiotic resistant bacteria, ARB) in the different ecosystems plays a central role in this strategy (Finley et al., 2013). The aquatic environments (and in particular freshwaters) could act as a natural pool of resistances (Olanrewaju et al., 2019). Because often impacted by anthropogenic activities and subjected to the release of antibiotics, they can favor the acquisition and dissemination of ARGs and, even, stimulate their transfer into pathogenic bacteria of clinical interest (Marti et al., 2014; Suzuki et al., 2017; Nnadozie and Odume, 2019). The latter can come back to humans, e.g., through recreational and fishery activities (Leonard et al., 2018; Syrova et al., 2018) and the consumption of raw seafood (Mughini-Gras et al., 2019), leading to antibiotic resistant bacterial infections. Animals living in aquatic environments may exacerbate these issues offering refuge to ARB and allochthonous pathogenic bacteria, and providing a niche that allows for the persistence of bacteria carrying resistances (Fu et al., 2017; Hong et al., 2018). In this context, 
the microbiome of freshwater meiofauna may constitute a neglected source of ARGs and pathogenic ARB for humans and animals.

The meiofauna designate a functional group of small animals living both in marine and freshwater environments with dimensions small enough to pass through a $1000-\mu \mathrm{m}$ mesh net but bigger than $42-\mu \mathrm{m}$ mesh net size (Fenchel, 1978; Higgins and Thiel, 1988; Schmid et al., 2000), mostly from sediment-associated (benthic) habitats, but not only (Traunspurger and Majdi, 2017). On this basis, meiofauna are often divided in permanent (organisms spending their whole life cycle as meiofauna) or temporary (juvenile stages of animals, such as insects, that grow into macrofauna) (Stead et al; 2005; Schmid-Araya et al., 2020), and constitute a trophic link between microbial primary production and higher trophic levels (Schmid-Araya and Schmid, 2000; Ptatscheck et al., 2020). They can also be found on rocks, wood, algae, plants and animals (Pinto et al., 2013). Meiofaunal organisms are ubiquitous and extremely diverse, comprising representatives from almost all the known animal phyla (with some phyla exclusive to meiofauna) (Giere, 2009; Fontaneto et al., 2015), hence constituting useful biological models for comprehensive, modern ecological assessments (Giere, 2009). Meiofauna play a major role in aquatic ecosystem processes: decomposition of organic material, nutrient cycling and energy flow, bioerosion and bioturbation of bottom sediment (Adámek and Maršálek, 2013; Prather et al., 2013). They are an important food source to a variety of animals that could not survive without them (Schmid-Araya and Schmid, 2000; Ptatscheck et al., 2020), and respond rapidly to environmental changes, given their high turnover rates (Zeppilli et al., 2015). For these reasons, they have been widely proposed as bio-indicators of the quality of aquatic ecosystems (Zeppilli et al., 2015) and used to determine the impact of human activities and pollution in the environment (Schratzberger and Somerfield, 2020). In view of this, they could represent an interesting model for the study of the spread of the resistance traits in aquatic systems, but their role as carriers of ARB is still largely unexplored. Meiofauna have been extensively studied in the past decades with a conspicuous number of publications in recent years (Majdi et al., 2020). Most of these studies investigated marine meiofauna, while little attention has been paid to the freshwater compartment (Majdi et al., 2020). Similarly, the contribution of freshwater meiofauna to the spread of resistances in the environment is scarcely explored. The aim of this review is to summarize the actual knowledge about the role of freshwater meiofauna as carriers of ARB, in particular, of human and animal potentially pathogenic bacteria and ARGs. We selected the most studied taxa of freshwater meiofauna and analyzed the collected literature, finally highlighting what has been found and what has to be addressed by future research efforts to fill the still lasting knowledge gaps.

\section{METHODS}

As above stated, the term "meiofauna" defines a heterogeneous set of small animals, covering almost all animal phyla, with a broad range of functional groups that have key roles in different ecosystems (Schratzberger and Ingels, 2018). Given this, we decided to make a selection of taxa, associated to freshwater meiofauna, on the basis of the results obtained from field studies (Majdi et al., 2017; Ptatscheck et al., 2020), which investigated lake and streams, and the evidence from recent literature (for a summary of the main findings see Majdi et al., 2020). Therefore, we chose the ten most studied taxa of freshwater meiofauna (Chironomidae, Cladocera, Copepoda, Gastrotricha, Nematoda, Oligochaeta, Ostracoda, Platyhelminthes, Rotifera, Tardigrada) (Tab. 1) and performed a survey on Clarivate Web of Science (WOS) on $16^{\text {th }}$ July 2021, using the keywords (in all fields): [(taxa* AND "antimicrobial resistance") OR (taxa* AND "antibiotic* resistan*")], for example [(cladocer* AND "antimicrobial resistance") OR (cladocer* AND "antibiotic* resistan*”)], in the case of antibiotic resistance, and [(taxa* AND "microb*") OR (taxa* AND "pathog*")], in the case of microbiome/pathobiome. Specifically, for Daphnia (which is a largely recognized model organism), the search was done as follow: [(daphnia AND "antimicrobial resistance") OR (daphnia AND "antibiotic* resistan*")] to show an example. We did the same for the terms "naupli*" and "turbellaria" (an improper word used in the past to refer to free-living flatworms). We limited the output to research articles provided with impact factor, while other documents (e.g., review, book chapter, others) were discarded. Then, we evaluated the articles one by one and selected those of interest (e.g., articles actually focused on the investigation

Tab. 1. List of the selected meiofaunal taxa and relative association with studies on antibiotic resistance.

\begin{tabular}{ll} 
Selected taxa & Association with ARGs/ARB \\
Chironomidae & Yes \\
\hline Cladocera & Yes \\
\hline Copepoda & Yes ${ }^{*}$ \\
\hline Gastrotricha & No \\
\hline Nematoda & No \\
\hline Oligochaeta & No \\
\hline Ostracoda & No \\
\hline Platyhelminthes & No \\
\hline Rotifera & Yes ${ }^{*}$ \\
\hline Tardigrada & No \\
\hline As part of freshwater communities. &
\end{tabular}


of the antibiotic resistance in freshwater meiofauna). Regarding the antibiotic resistome (total content of ARGs), we kept all the articles retrieved. For the microbiome/pathobiome (total content, in the meiofauna microbiome, of genera containing bacteria potentially pathogenic to humans and other animals), when the number of records associated with a specific taxon was scarce, we retained all the studies; in case of an elevated number of hits, we selected the most representative articles, preferring the ones focused on the whole microbiome rather than single pathways.

\section{RESULTS}

\section{Meiofauna microbiome and pathobiome}

The community of microorganisms inhabiting a defined environment, such as the body cavities of a multicellular organism, is defined as a microbiome (Marchesi and Ravel, 2015). Human and animal microbiomes are known to have a beneficial effect on the host (Sommer and Bäckhed, 2013). The microbiome affects the host's immunity, development, metabolism, nutritional habits, mating and behavior (Turnbaugh et al., 2006; Rhee et al., 2009; Sharon et al., 2010; Shin et al., 2011; Foster and McVey Neufeld, 2013; David et al., 2014) and in some cases it can cause harm to the host by contributing to disease. The pathobiome represents the portion of the microbiome associated with a reduced health status in the host as a result of their interaction (Bass et al., 2019; Vayssier-Taussat et al., 2014). While microbial communities hosted by humans and other large vertebrates are complex and it is difficult to interpret their role on the host system (Waldor et al., 2015), meiofauna offer a more convenient model to study microbiome-host interactions (e.g., Olszewski et al., 2020). Yet, little is known about host-microbiome interactions in freshwater especially for meiofauna. In this section, we focus on two main points: which microbial taxa are mainly represented in freshwater meiofauna and, among them, which bacterial genera might be potentially pathogenic to human and other animals and cross spread to the other food web levels.

Ostracods are small crustaceans, inhabiting both marine and freshwater ecosystems. They have the ability to hatch from eggs resistant to adverse environmental conditions, and rapidly populate available water bodies (Rossi et al., 2012; Vandekerkhove et al., 2013). Furthermore, some species show short life cycle and parthenogenetic reproduction and, therefore, are pioneering organisms of temporary freshwaters (Martins et al., 2009; Olmo et al., 2016). Olszewski and colleagues (2020) investigated the bacteria associated with two species of freshwater ostracods Sclerocypris tuberculata and Potamocypris mastigophora co-cultured in laboratory conditions after being collected from a lake sediment sample. Despite the fact they were grown in the same experimental conditions, each ostracod hosted distinct bacterial communities. Especially the family Comamonadaceae (Betaproteobacteria) dominated in P. mastigophora and the Aeromonadaceae (Gammaproteobacteria) in S. tuberculata. The latter represented on average $38 \%$ of the total community composition of $S$. tuberculata while, in $P$. mastigophora, this family represented about $0.15 \%$ of the total microbiome. The genus Acinetobacter, which comprises potential pathogens for humans (Howard et al., 2012), conversely was more abundant in P. mastigophora representing $0.42 \%$ towards $0.09 \%$ in $S$. tuberculata, suggesting that different species of ostracods within the same experimental system can diverge in the microbiome composition. In general, ostracod-associated bacterial communities (Jarett et al., 2013; Schön et al., 2019; Olszewski et al., 2020), when looking at a higher taxonomic level (phylum), show a composition similar to that of the bacterial communities of other freshwater invertebrates (i.e., Daphnia) (SisonMangus et al., 2015; Macke et al. 2017), while most differences are at lower diversity levels.

Another important group of small crustaceans in the meiofauna is the Cladocera, constituting the main secondary consumers in aquatic ecosystems, as they show the highest rate of filtration among small freshwater invertebrates (Dumont and Negrea, 2002). Organisms belonging to the genus Daphnia are filter feeders and play a central role in the food webs of lakes and ponds, as consumers of bacterioplankton and phytoplankton, and as preys of invertebrate and fish (Olanrewaju et al., 2019). Furthermore, Daphnia has been extensively used as a model organism in biological research (Ebert, 2005). Several studies described the microbiome of Daphnia species (Freese and Schink, 2011; Sison-Mangus et al., 2015; Macke et al., 2017; Eckert et al., 2021). These organisms harbor a beneficial and active microbiome, composed by both resident and transient bacterial species (Grossart et al., 2009; Eckert and Pernthaler, 2014; SisonMangus et al., 2015; Peerakietkhajorn et al., 2016). Eckert and colleagues (2016) made an experiment adding Daphnia to a natural freshwater bacterial community. The authors found that the genus Flavobacterium composed over 50\% of the daphnia-associated microbiome. Flavobacterium contains many opportunistically growing taxa and some potential fish pathogens (Nematollahi et al., 2003; Neuenschwander et al., 2015). Other human potentially pathogenic genera found were Pseudomonas, Klebsiella, Brevundimonas and Acinetobacter despite being less abundant compared to Flavobacterium. Similarly, Callens and colleagues (2020) found that the composition of the environmental bacterial community has a major influence on the Daphnia gut bacterial community, and described a similar pathobiome that included Brevundimonas, Acinetobacter, Pseudomonas, and Flavobacterium. Akbar and colleagues (2020) studied the effect of antibiotics on the gut microbiome of Daphnia, and observed that, in the presence of tetracycline, the abundance of Pseudomonadaceae and 
Sphingobacteriaceae increased in the Daphnia microbiome. Qi and colleagues (2009) performed a metagenomic analysis of different species of Daphnia: one dataset from clones of $D$. pulex and D. pulicaria and two datasets from one clone of D. magna. Apart from Comamonadaceae (Proteobacteria), which represented the most part of the metagenomes, other taxa present in all datasets included the genera Flavobacterium, Rhodobacter, Chromobacterium, Methylibium, Bordetella, Burkholderia, and Cupriavidus whereas some sequences exclusive to $D$. pulex and the $D$. pulicaria datasets were classified within the Aeromonas, Pseudomonas, and Delftia genera (Qi et al., 2009). Among the above mentioned taxa, some Flavobacteria are opportunistic fish pathogens (e.g., of salmons) (Loch and Faisal, 2015), Pseudomonas and Bordetella include animal and human pathogenic species (Bergan, 1981; Hamidou Soumana et al., 2017) while Aeromonas hits retrieved by the authors were attributable to A. hydrophila, which is an opportunistic pathogen of humans (Stratev and Odeyemi, 2016), and A. salmonicida, a fish pathogen (DallaireDufresne et al., 2014). Cooper and colleagues (2021) provided a differential analysis of Daphnia gut microbiome: they tested experimentally the effect of three antibiotics (aztreonam, erythromycin, sulfamethoxazole) on the gut microbiome. Among the treatments and the control, they found significant differences in the abundance of potentially pathogenic genera: Pseudomonas, Aeromonas and Flavobacterium.

Eckert and colleagues (2021) produced a large, comprehensive study of the microbiome associated with freshwater rotifers, cladocerans, and copepods and surrounding waters focusing on the core microbiome shared between specimens and considering the three groups of animals separately. They found that common families were Flavobacteriaceae (representing 3-21\% of core zOTUs) and Pseudomonadaceae (representing 1-25\% of core zOTUs).

Chironomidae larvae account for a high percentage of the total biomass of benthic microscopic fauna (Kornijów, 1997; Horppila et al., 2000). They represent a very important item in the fish food of various ecological groups, and microbes are intrinsic to their guts and surfaces (Ding et al., 2021). Halpern and Senderovich (2015) found that the microbiome of chironomid egg masses and larvae degraded various toxicants, enabling their host to live in polluted environments. Moore and colleagues (2003) described the survival of Salmonella enterica, serovar Typhimurium mr-DT-104 (a human and animal pathogen, Besser et al., 2000), in freshwaters and freshwater sediments. The results obtained by the researchers indicated that Salmonella enterica could survive in aquatic sediments for several months (Moore et al., 2003). Furthermore, they also demonstrated the uptake of salmonellae by chironomid larvae and adults suggesting they could be vectors of salmonellae in both aquatic and terrestrial environments. In 2007, Aeromonas was discovered for the first time to be able to colonize chironomid egg masses, like Vibrio cholerae does (Halpern et al., 2007; Senderovich et al., 2008). Some authors highlighted the relationship between chironomids and some species of the Aeromonas genus; for instance, Laviad and Halpern (2016) investigated the complicated mutualistic relationship that seems to exist between chironomids and Aeromonas species. Indeed, Aeromonas species can be found in elevated numbers in the egg masses through all seasons of the year, and are able to control chironomid eggs viability both degrading the eggs and protecting them from toxic metals (Laviad and Halpern, 2016). Looking at human pathogenic species, Beaz-Hidalgo and colleagues (2012) isolated from chironomid egg masses Aeromonas sanarellii and Aeromonas taiwanensis previously described in hospitalized patients and harboring Shiga toxins (Alperi and Figueras, 2010). In conjugation experiments under the pressure of antibiotics, resistant (and potentially pathogenic) Enterococcus, Escherichia and Flavobacterium emerged in gut isolates of chironomid larvae (Ding et al., 2021).

These studies show how the microbiome and its freshwater hosts may exhibit complex relationships. Meiofauna may play a critical role in maintenance and spread of microbes since, while transferring energy to the higher trophic levels (Schratzberger and Ingels, 2018), also components of the microbiome might be carried and transferred. However, information about the specificity (both host and environmental) of bacterial communities associated with different meiofaunal species is still lacking, and further studies are needed to answer questions about their role in carrying and spreading ARGs. The relevance of human and animal pathogens associated with meiofauna (Tab. 2) is greater in the presence of antibiotic resistance in the same microbiome, and even greater if the same pathogens are carriers of ARGs, as shown in the following section.

\section{Antibiotic resistant bacteria and antibiotic resistance genes associated with meiofauna}

Meiofauna represent a natural reservoir for bacteria (Laviad and Halpern, 2016) (including ARB and their associated ARGs). Furthermore, the physical and chemical conditions, inside and on the surface of some of these animals, differ from those of the surrounding water and, therefore, select for different bacterial communities that otherwise may not thrive in open water conditions (Tang et al., 2010). Meiofauna can also enrich ARGs in their gastrointestinal tracts by preying on bacterioplankton (Kathol et al., 2011) and phytoplankton (and its attached bacteria), potentially carrying ARGs, and, in this way, become a vector for their spread due to the long-range migration of these animals (Tang, 2005; Grossart et al., 2010). Studies about ARGs and ARB in freshwater meiofauna are scarce. Our bibliography search led to only 8 published studies, most of them focused on Chironomidae or Daphnia. 
Freshwater meiofauna as carriers of antibiotic resistance

Tab. 2. List of the research articles reporting potential pathogens in meiofauna.

\begin{tabular}{|c|c|c|c|c|c|c|c|}
\hline Group & Taxa & Environment & Location & $\begin{array}{l}\text { Sediment/ } \\
\text { water column }\end{array}$ & $\begin{array}{l}\text { Potentially } \\
\text { pathogenic } \\
\text { genera }\end{array}$ & $\begin{array}{l}\text { Identification } \\
\text { methodology }\end{array}$ & Reference \\
\hline Ostracoda & $\begin{array}{l}\text { Sclerocypris } \\
\text { tuberculata }\end{array}$ & Temporary lake & $\begin{array}{l}\text { Makgadikgadi } \\
\text { depression, } \\
\text { Botswana }\end{array}$ & Sediment & $\begin{array}{l}\text { Acinetobacter } \\
(0.09 \%)\end{array}$ & $\begin{array}{l}454 \\
\text { pyrosequencing }\end{array}$ & $\begin{array}{l}\text { Olszewski et al., } \\
2020 .\end{array}$ \\
\hline Ostracoda & $\begin{array}{l}\text { Potamocypris } \\
\text { mastigophora }\end{array}$ & Temporary lake & $\begin{array}{l}\text { Makgadikgadi } \\
\text { depression, } \\
\text { Botswana }\end{array}$ & Sediment & $\begin{array}{l}\text { Acinetobacter } \\
(0.42 \%)\end{array}$ & $\begin{array}{l}454 \\
\text { pyrosequencing }\end{array}$ & $\begin{array}{l}\text { Olszewski et al., } \\
2020 .\end{array}$ \\
\hline Cladocera & Daphnia & Garden pond & Verbania, Italy & Water column & $\begin{array}{l}\text { Flavobacterium } \\
(>50 \%), \\
\text { Pseudomonas, } \\
\text { Klebsiella, } \\
\text { Brevundimonas, } \\
\text { Acinetobacter }\end{array}$ & Illumina MiSeq & $\begin{array}{l}\text { Eckert et al., } \\
2016 .\end{array}$ \\
\hline Cladocera & Daphnia & $\begin{array}{l}\text { Laboratory } \\
\text { maintained } \\
\text { culture, } \\
\text { inoculated with } \\
\text { microbial } \\
\text { communities } \\
\text { deriving from: } \\
\text { natural pond, } \\
\text { fish pond, } \\
\text { water reservoir, } \\
\text { hay extract }\end{array}$ & Belgium & Water & $\begin{array}{l}\text { Brevundimonas, } \\
\text { Acinetobacter, } \\
\text { Pseudomonas, } \\
\text { Flavobacterium }\end{array}$ & Illumina MiSeq & $\begin{array}{l}\text { Callens et al., } \\
2020 .\end{array}$ \\
\hline Cladocera & Daphnia pulex & $\begin{array}{l}\text { Laboratory } \\
\text { maintained } \\
\text { cultures, } \\
\text { supplied with } \\
\text { tetracycline }\end{array}$ & USA & Water & $\begin{array}{l}\text { Flavobacterium, } \\
\text { Bordetella, } \\
\text { Aeromonas, } \\
\text { Pseudomonas }\end{array}$ & $\begin{array}{l}454 \\
\text { pyrosequencing }\end{array}$ & Qi et al., 2009. \\
\hline Cladocera & $\begin{array}{l}\text { Daphnia } \\
\text { pulicaria }\end{array}$ & $\begin{array}{l}\text { Laboratory } \\
\text { maintained } \\
\text { cultures, } \\
\text { supplied with } \\
\text { tetracycline }\end{array}$ & USA & Water & $\begin{array}{l}\text { Flavobacterium, } \\
\text { Bordetella, } \\
\text { Aeromonas, } \\
\text { Pseudomonas }\end{array}$ & $\begin{array}{l}454 \\
\text { pyrosequencing }\end{array}$ & Qi et al., 2009. \\
\hline Cladocera & Daphnia magna & $\begin{array}{l}\text { Laboratory } \\
\text { maintained } \\
\text { cultures }\end{array}$ & Switzerland & Water & $\begin{array}{l}\text { Flavobacterium, } \\
\text { Bordetella }\end{array}$ & $\begin{array}{l}454 \\
\text { pyrosequencing }\end{array}$ & Qi et al., 2009. \\
\hline Cladocera & Daphnia & $\begin{array}{l}\text { Farm harvested, } \\
\text { laboratory } \\
\text { maintained } \\
\text { cultures }\end{array}$ & UK & Water & $\begin{array}{l}\text { Pseudomonas, } \\
\text { Aeromonas, } \\
\text { Flavobacterium }\end{array}$ & Illumina MiSeq & $\begin{array}{l}\text { Cooper et al., } \\
2021 .\end{array}$ \\
\hline Chironomid larvae & $\begin{array}{l}\text { Chironomus } \\
\text { tentans }\end{array}$ & $\begin{array}{l}\text { Experimental } \\
\text { tanks maintained } \\
\text { cultures }\end{array}$ & USA & $\begin{array}{l}\text { Water and } \\
\text { sediment }\end{array}$ & $\begin{array}{l}\text { Salmonella } \\
\text { enterica }\end{array}$ & $\begin{array}{l}\text { Enumeration by } \\
\text { spread-plate } \\
\text { counts }\end{array}$ & $\begin{array}{l}\text { Moore et al., } \\
2003 \text {. }\end{array}$ \\
\hline Chironomid egg masses & $\begin{array}{l}\text { Taxa not } \\
\text { specified }\end{array}$ & $\begin{array}{l}\text { Waste } \\
\text { stabilization } \\
\text { pond, river water }\end{array}$ & Israel & $\begin{array}{l}\text { Water, artificial } \\
\text { oviposition } \\
\text { structure }\end{array}$ & Vibrio cholerae & $\begin{array}{l}3100 \text { Genetic } \\
\text { Analyzer }\end{array}$ & $\begin{array}{l}\text { Halpern et al., } \\
2007 .\end{array}$ \\
\hline Chironomid egg masses & $\begin{array}{l}\text { Taxa not } \\
\text { specified }\end{array}$ & $\begin{array}{l}\text { Waste } \\
\text { stabilization } \\
\text { pond, river water }\end{array}$ & Israel & $\begin{array}{l}\text { Water, artificial } \\
\text { oviposition } \\
\text { structure }\end{array}$ & $\begin{array}{l}\text { Aeromonas } \\
\text { sanarellii, } \\
\text { Aeromonas } \\
\text { taiwanensis }\end{array}$ & $\begin{array}{l}\text { m-Aeromonas } \\
\text { agar plating, } \\
\text { genotyping by } \\
\text { ERIC-PCR }\end{array}$ & $\begin{array}{l}\text { Beaz-Hidalgo } \\
\text { et al., } 2012 .\end{array}$ \\
\hline Chironomid larvae & Chironomidae & River water & $\begin{array}{l}\text { Panlong River, } \\
\text { China }\end{array}$ & $\begin{array}{l}\text { Water column } \\
\text { and sediment }\end{array}$ & $\begin{array}{l}\text { Enterococcus, } \\
\text { Escherichia, } \\
\text { Flavobacterium }\end{array}$ & Illumina MiSeq & Ding et al., 2021. \\
\hline Freshwater Rotifera & $\begin{array}{l}\text { Adineta vaga, } \\
\text { Brachionous } \\
\text { quadridentatus, } \\
\text { Epiphanes senta, } \\
\text { Euchlanis dilatata, } \\
\text { Keratella quadrat } \\
\text { Keratella serrulatc } \\
\text { Lecane elsa, } \\
\text { Lecane inermis, } \\
\text { Polyarthra sp., } \\
\text { Rotaria macrura, } \\
\text { Rotaria rotatoria }\end{array}$ & $\begin{array}{l}\text { Lakes, ponds, } \\
\text { followed by } \\
\text { experimental } \\
\text { cultures } \\
t, \\
\text { ta, } \\
\text { ta, }\end{array}$ & Italy & Water column & $\begin{array}{l}\text { Pseudomonas } \\
\text { present in the } \\
\text { core microbiome }\end{array}$ & Illumina MiSeq & $\begin{array}{l}\text { Eckert et al., } \\
2021 .\end{array}$ \\
\hline
\end{tabular}


Regarding Chironomidae, as underlined in the previous section, there are some specific genera like Vibrio and Aeromonas widely reported to inhabit their surface or their gut. In particular, Aeromonas species are known for being resistant to $\beta$-lactams and have been associated with human diseases (Laviad and Halpern, 2016). In 2012, Beaz-Hidalgo and collaborators studied two isolates from chironomid egg masses, Aeromonas taiwanensis and A. sanarellii, testing the resistance of these two strains against 19 antimicrobials (Beaz-Hidalgo et al., 2012). As expected, all strains were resistant to $\beta$-lactams (ampicillin, cefalotin and ertapenem), and $75 \%$ of the isolates were resistant to a combination of amoxicillin and clavulanic acid, too. The strains showed different susceptibility ( 25 to $78 \%$ sensitivity) to 12 of the 19 tested antibiotics (amikacin, aztreonam, cefepime, cefotaxime, ceftazidime, ciprofloxacin, gentamicin, piperacillintazobactam, tigecycline, tobramycin, trimethoprimsulfamethoxazole, and imipenem) (Beaz-Hidalgo et al., 2012; Laviad and Halpern, 2016). Similarly, Basu and collaborators (2010) studied the ARB load in chironomids, but in this case in larval isolates, testing eight antibiotics (ampicillin, chloramphenicol, colistin methanesulfonate, kanamycin, nalidixic acid, nitrofurantoin, streptomycin and tetracycline). They detected a wide incidence of antibiotic resistant bacteria in the larval isolates of an experimental pond and in sewage drain water. The strains isolated from the drain water were less susceptible than those isolated from the pond. The drain water isolates were found resistant to all the antibiotics except colistin methanesulfonate, and $100 \%$ of the isolated strains were resistant to ampicillin and chloramphenicol. While the isolates of the pond were $100 \%$ resistant to ampicillin, only $50 \%$ of them showed resistance to chloramphenicol and nitrofurantoin, and no resistances were found for the other tested antibiotics (Basu et al., 2010). sul2 (a sulfonamide resistance gene), tetA (a tetracycline resistance gene), and kan (kanamycin resistance gene) were detected by quantitative Real Time PCR (qPCR), in the microbiome of chironomid larvae from Panlong River (China) (Ding et al., 2021). In this case, the authors made the comparison with the water and sediment of the river, and performed a differential detection of sul2 in various parts of the larvae body, and at different stages of their development. The genes sul2, tetA, and kan were detected in the chironomid larvae, but the authors deepened the study only for sul2. This gene was more abundant in the microbiome of the larvae than in water and sediment. It was found in the head, chest, and abdomen of the larvae, with the highest concentration $\left(9.1 \times 10^{-4}\right.$ copies/16S rRNA gene copy) found in the gut. Also, its content changed significantly during the different developmental stages of the larvae, increasing from the second $\left(3.0 \times 10^{-4}\right.$ copies/16S rRNA gene copy) to the fourth $\left(9.1 \times 10^{-4}\right.$ copies/16S rRNA gene copy) larval instars but decreasing in the adult stage $\left(2.0 \times 10^{-5}\right.$ copies $/ 16 \mathrm{~S}$ rRNA gene copy) (Ding et al., 2021).
In the case of Daphnia, their abundant and rare associated bacteria could be carriers of ARGs (e.g., Flavobacterium, Pseudomonas, Klebsiella, Citrobacter, Acinetobacter, Serratia and Rhizobium) (Eckert et al., 2016). Olanrewaju and colleagues (2019) made a conjugation experiment with a vancomycin-resistant donor strain (Enterococcus faecalis carrying the van A resistance gene), and two vancomycin-susceptible and rifampicin-resistant recipient E. faecalis strains in the presence of Daphnia magna or Daphnia pulex. The isolates were prior tested for resistance to eight antibiotics (ciprofloxacin, imipenem, linezolid, rifampicin, streptomycin, trimethoprim, teicoplanin, and vancomycin) using the disk diffusion assay and showing resistance to two or three antibiotics. At the end of the experiment the presence of vanA (evaluated by PCR) was used to confirm the transfer of vancomycin resistance between the donor and recipient strains in the treatment with only D. magna, D. pulex, or both Daphnia species. Successful conjugation was detected in all the cases within a 4-h feeding period with transconjugants expressing resistance to vancomycin and rifampicin. In another experiment, Eckert and colleagues (2016) tested whether the presence of Daphnia could modulate the abundance of ARGs, following the tetracycline resistance gene tet $\mathrm{A}$, which is nearly constitutively present in the bacterial community of Lake Maggiore, in Italy (Di Cesare et al., 2015). The presence of Daphnia resulted in lower abundances of tet $\mathrm{A}$ in the water, however, the gene was still detected within the animals in similar abundances as found in the water of the Daphnia-free treatment, suggesting a potential persistence or proliferation within the Daphnia microbiome (Eckert et al., 2016). Cooper and Cressler (2020) used a metagenomic approach to characterize the microbiome present in Daphnia magna and get insight into the potential metabolic interactions between host and microbes. Even if it was not the main aim of the study, multiple genes and pathways involved in antibiotic resistance and detoxification were found in the bacterial metagenome-assembled genomes from the Daphnia isolates. The Pedobacter sp. genome encoded the multidrug efflux pump MdlAB/SmdAB and genes for macrolide export (macA, macB), while the Polaromonas sp. genome encoded the AcrAB-TolC/SmeDEF efflux pump (Cooper and Cressler, 2020).

Regarding other meiofaunal groups, studies on the presence of ARGs in their associated bacteria are even more difficult to find. Chaix and colleagues (2017) tested sixteen antibiotics (ampicillin, amoxicillin plus clavulanic acid, ticarcillin, ticarcillin plus clavulanic acid, piperacillin, piperacillin plus tazobactam, cefotaxime, cefoxitin, cefepime, ertapenem, imipenem, gentamicin, tobramycin, norfloxacin, ciprofloxacin, trimethoprim plus sulfamethoxazole) using the disc diffusion method, in Aeromonas populations associated with copepods and in the water of the Seine estuary. In this case, the researchers found no signif- 
icant difference between Aeromonas antibiotic resistance phenotypes from the water column and copepods, except for the resistance to a combination of amoxicillin plus clavulanic acid and cefoxitin, which resulted to be higher in water. However at species level, the isolates of $A$. salmonicida from copepods were three times more resistant to ticarcillin plus clavulanic acid than the isolates from water (Chaix et al., 2017). Xue and colleagues (2021) quantified (by qPCR) 26 ARGs encoding resistance to six classes of antibiotics (sulfonamides, tetracyclines, quinolones, macrolides, chloramphenicol and $\beta$-lactams), two integron integrase genes and seven transposases in phytoplankton-zooplankton (mainly rotifers, copepods and cladocerans) associated bacteria. tet $\mathrm{Z}$, tet $\mathrm{M}$, tet $\mathrm{C}$ (conferring resistance to tetracycline) and floR (against florfenicol) were the dominant ARG subtypes $(\sim 70 \%$ relative abundance). In this study the authors also found a high abundance of mobile genetic elements, correlated with ARGs, suggesting that they may play a role in the propagation of ARGs in the aquatic communities (Xue et al., 2021).

\section{DISCUSSION}

The spread of antibiotic resistance worldwide has led to the awareness of the central role played by the environment and aquatic ecosystems in the spread of resistant and/or pathogenic bacteria, with potentially harmful outcomes if reaching the clinical settings. It has been demonstrated that freshwaters and their biota could promote the development and persistence of resistances in different compartments (water column, sediment, suspended particles and aquatic animals) (Di Cesare et al., 2020; Garner et al., 2017; Jia et al., 2018; Jia et al., 2020; Sathicq et al., 2021); however the contribution of freshwater meiofauna remains still largely unexplored.

In this review, we collected the data available up to now on the role of freshwater meiofauna as carriers of ARGs and potentially pathogenic bacteria and ARB. Meiofauna closely interact with bacteria (e.g., increasing bacterial denitrification, reducing bacterial mineralization of organic pollutants, and contributing to macroalgae decomposition and nutrient recycling) (Näslund et al., 2010; Bonaglia et al., 2014; Herrera et al., 2017; Schratzberger and Ingels, 2018), and several species feed on planktonic microorganisms (Kathol et al., 2011).

The bacterial communities associated with meiofauna surfaces and gut have proven to be complex and may include human and animal potentially pathogenic bacteria that can find in meiofauna a refuge and sustaining conditions (Moore et al., 2003; Beaz-Hidalgo et al., 2012; Eckert et al., 2016; Laviad and Halpern, 2016; Callens et al., 2020; Olszewski et al., 2020; Cooper et al., 2021; Ding et al., 2021). In addition, several of the reviewed studies reported that the meiofauna-derived isolates, in some cases potentially path- ogenic strains, were resistant to a broad range of antibiotics (Halpern et al., 2007; Basu et al., 2010; Beaz-Hidalgo et al., 2012; Laviad and Halpern, 2016; Chaix et al., 2017); whereas others confirmed the role of meiofauna microbiome as carriers of ARGs (Eckert et al., 2016; Cooper and Cressler, 2020; Ding et al., 2021; Xue et al., 2021).

\section{Limitations of current researches}

In this review, we proposed the freshwater meiofauna microbiome as an understudied carrier for antibiotic resistance. However, we could only focus on a small set of freshwater organisms and environments. Large gaps in the understanding of ARG dynamics in freshwater meiofauna are still present due to the variety of methodological approaches, target animals, and different levels of anthropogenic pollution of the investigated environments, which makes it difficult to arrive at a more general conclusion. Indeed, despite the fact that we selected 10 meiofaunal taxa, only for four of them (namely Chironomidae, Cladocera, Copepoda, Rotifera) we found studies concerning their association with antibiotic resistance (Tab. 3). However, meiofauna comprise a wide group of organisms that differ for morphology, trophic strategy and habitat (Fonseca et al., 2018), and this might correlate with diverse features in carrying ARGs. Furthermore, it could be valuable addressing the differences in the antibiotic resistome composition and abundance between sediment and water column relatively to meiofaunal taxa, with a focus on benthic ones, since it has been shown that sediment could act as a long term reservoir of ARGs (Di Cesare et al., 2020).

\section{Comparison with other organisms}

The limited numbers of studies and the lack of a wider metagenomic approach (e.g., shotgun metagenomics) do not consent to draw a univocal picture of the ARGs specificity and trends in meiofauna bacterial communities. Nevertheless, some considerations can be made, in part comparing the results obtained in freshwater meiofauna to those observed in marine meiofauna or bigger invertebrates. For example, in the gut microbiome of a soil invertebrate, the earthworm Metaphire guillelmi, experimentally exposed to tetracycline, the resistance genes tet $\mathrm{A}$, tet $\mathrm{C}$, and tet $\mathrm{W}$ increased in concentration with growing antibiotic doses (Chao et al., 2019). Likewise, Nasri and colleagues (2020) exposed an assemblage of marine nematodes to ciprofloxacin (a fluoroquinolone antibiotic) and observed the alteration of density and structure of their bacterial community, suggesting a selection due to the antibiotic and the possible presence of ARGs and ARB in the nematode microbiome. Similar findings could be observed also in freshwater meiofauna, since these animals have proven to be able to live in presence of antibiotics (Quinlan et al., 2011) and in antibiotic polluted areas (Xue et al., 2021). 


\section{Meiofauna microbiome flexibility}

Eckert and colleagues (2021) proposed a pronounced flexibility of the microbiome composition as a common trait among the considered taxa (freshwater rotifers, cladocerans and copepods), finding similarity between the hosted microbiome and the water column community composition. Conversely, diverging results were found in both freshwater and marine benthic environments. Different freshwater species of ostracods were showing a host-specific microbiome (Olszewski et al., 2020) and coexisting cryptic species of the Litoditis marina complex were also displaying substantial differences in their associated micro- biomes, suggesting that different meiofaunal taxa might have diverse retention ability and flexibility towards the environmental microbiome, with a cascade effect on the pathobiome and antibiotic resistome. Meiofauna can accumulate ARGs from the surrounding environment (Eckert et al., 2016) and this enrichment could follow an anthropogenic pollution gradient (Ding et al., 2021), as also indirectly demonstrated by an higher level of resistance of bacteria isolated from chironomid larvae kept in sewage drain water in respect to the ones derived from animals grown in an experimental pond, suggesting that ARGs can find suitable conditions to spread within the meiofauna (Eckert et al., 2016). The antibiotic pollution occurring in

Tab. 3. List of the research articles on antibiotic resistance in meiofauna.

\begin{tabular}{|c|c|c|c|c|c|c|c|}
\hline Group & Environment & Location & Bacteria & Methodologies & Genes & Antibiotics & Reference \\
\hline Chironomid egg masses & $\begin{array}{l}\text { Waste } \\
\text { stabilization } \\
\text { pond }\end{array}$ & Northern Israel & $\begin{array}{l}\text { Aeromonas } \\
\text { taiwanensis } \\
\text { and Aeromonas } \\
\text { sanarellii }\end{array}$ & $\begin{array}{l}\text { Antibiotic } \\
\text { susceptibility } \\
\text { test }\end{array}$ & & 19 antibiotics & $\begin{array}{l}\text { Beaz-Hidalgo } \\
\text { et al., } 2012 .\end{array}$ \\
\hline Chironomid larvae & $\begin{array}{l}\text { Experimental } \\
\text { pond and drain } \\
\text { water }\end{array}$ & $\begin{array}{l}\text { Bardhaman, } \\
\text { India }\end{array}$ & $\begin{array}{l}\text { Aerobic } \\
\text { heterotrophic } \\
\text { bacterial } \\
\text { population } \\
\text { in the gut }\end{array}$ & $\begin{array}{l}\text { Microbial count } \\
\text { and antibiotic } \\
\text { susceptibility } \\
\text { test }\end{array}$ & & 8 antibiotics & Basu et al., 2010. \\
\hline Chironomidl arvae & $\begin{array}{l}\text { River sediment } \\
\text { and river water }\end{array}$ & $\begin{array}{l}\text { Shandong, } \\
\text { China }\end{array}$ & $\begin{array}{l}\text { Intestinal } \\
\text { bacteria of } \\
\text { Chironomidae } \\
\text { larvae }\end{array}$ & qPCR & $\begin{array}{l}\text { tetA, kan, sul2, } \\
\text { NDM-1, mcr-1 }\end{array}$ & & Ding et al., 2021. \\
\hline $\begin{array}{l}\text { Daphnia magna and } \\
\text { Daphnia pulex }\end{array}$ & $\begin{array}{l}\text { Cultured } \\
\text { continuously in } \\
\text { filtered and } \\
\text { autoclaved river } \\
\text { water }\end{array}$ & - & E. faecalis & $\begin{array}{l}\text { Antibiotic disk } \\
\text { diffusion assay, } \\
\text { PCR } \\
\text { amplification } \\
\text { of vancomycin } \\
\text { resistance genes } \\
\text { and DNA } \\
\text { sequencing }\end{array}$ & $\operatorname{van} \mathrm{A}$ & 8 antibiotics & $\begin{array}{l}\text { Olanrewaju et al., } \\
2019 .\end{array}$ \\
\hline Daphnia obtusa & $\begin{array}{l}\text { Surface lake } \\
\text { water }\end{array}$ & $\begin{array}{l}\text { Lake Maggiore, } \\
\text { Italy }\end{array}$ & E. coli & qPCR & tetA & & $\begin{array}{l}\text { Eckert et al., } \\
2016 .\end{array}$ \\
\hline Daphnia magna & Pond & - & $\begin{array}{l}\text { Bacterial } \\
\text { species present } \\
\text { in the Daphnia } \\
\text { magna } \\
\text { microbiome }\end{array}$ & $\begin{array}{l}\text { Shotgun } \\
\text { sequencing }\end{array}$ & $\begin{array}{l}\text { MdlAB/SmdAB, } \\
\text { macA, macB, } \\
\text { AcrAB-TolC/ } \\
\text { SmeDE, } \\
\text { BaeS-BaeR }\end{array}$ & & $\begin{array}{l}\text { Cooper and } \\
\text { Cressler, } 2020 .\end{array}$ \\
\hline $\begin{array}{l}\text { Phytoplankton- } \\
\text { zooplankton } \\
\text { communities }\end{array}$ & Urban river & Shannxi, China & $\begin{array}{l}\text { Phytoplankton- } \\
\text { zooplankton } \\
\text { associated } \\
\text { bacteria }\end{array}$ & qPCR & 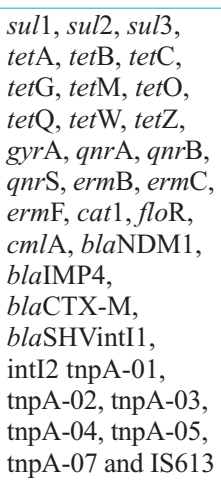 & , & $\begin{array}{l}\text { Xue et al., } \\
2021 .\end{array}$ \\
\hline Copepods & Estuary & Seine, France & Aeromonas & $\begin{array}{l}\text { Antibiotic } \\
\text { susceptibility } \\
\text { test }\end{array}$ & & 16 antibiotics & $\begin{array}{l}\text { Chaix et al., } \\
2017 .\end{array}$ \\
\hline
\end{tabular}


human impacted areas can contribute to the above mentioned findings (Xue et al., 2021).

\section{Horizontal gene transfer of ARGs}

Freshwater meiofauna can promote the spread and persistence of ARGs in the aquatic environments, via horizontal gene transfer, given the protective and suitable conditions within their body, especially in the gut, as demonstrated for other aquatic animals (Fu et al., 2017). In particular, the microbiome of the gut of chironomid larvae showed to have the highest ARG abundances in respect to those of other body sections (head, chest) and stimulates horizontal gene transfer of the resistance traits by conjugation (Ding et al., 2021). Other experimental findings supported that horizontal gene transfer of ARGs was enhanced in the presence of meiofauna and that it was a major mechanism for their spread, through mobile genetic elements (conjugative plas- mids and transposons) and integron integrases (Olanrewaju et al., 2019; Ding et al., 2021; Xue et al., 2021).

\section{ARGs spread through meiofauna}

We highlighted that the larval state can influence the antibiotic resistome: the microbiome of larval instars of chironomids was richer in ARGs than that of the adults (Ding et al., 2021). This is of particular interest because larvae are preyed by fishes and, in this way, promote the spread and magnification of resistance along the food chain (Ding et al., 2021), as reported for marine meiofauna, which demonstrated to be carriers of pathogenic ARB in aquaculture systems (Kalatzis et al., 2016; Sahandi et al., 2019; Hurtado et al., 2020). As a consequence, the antibiotic resistance could be transferred to humans when fish and crustaceans or mollusks were consumed, especially as raw food (Mughini-Gras et al., 2019) (Fig. 1). Meiofauna can also

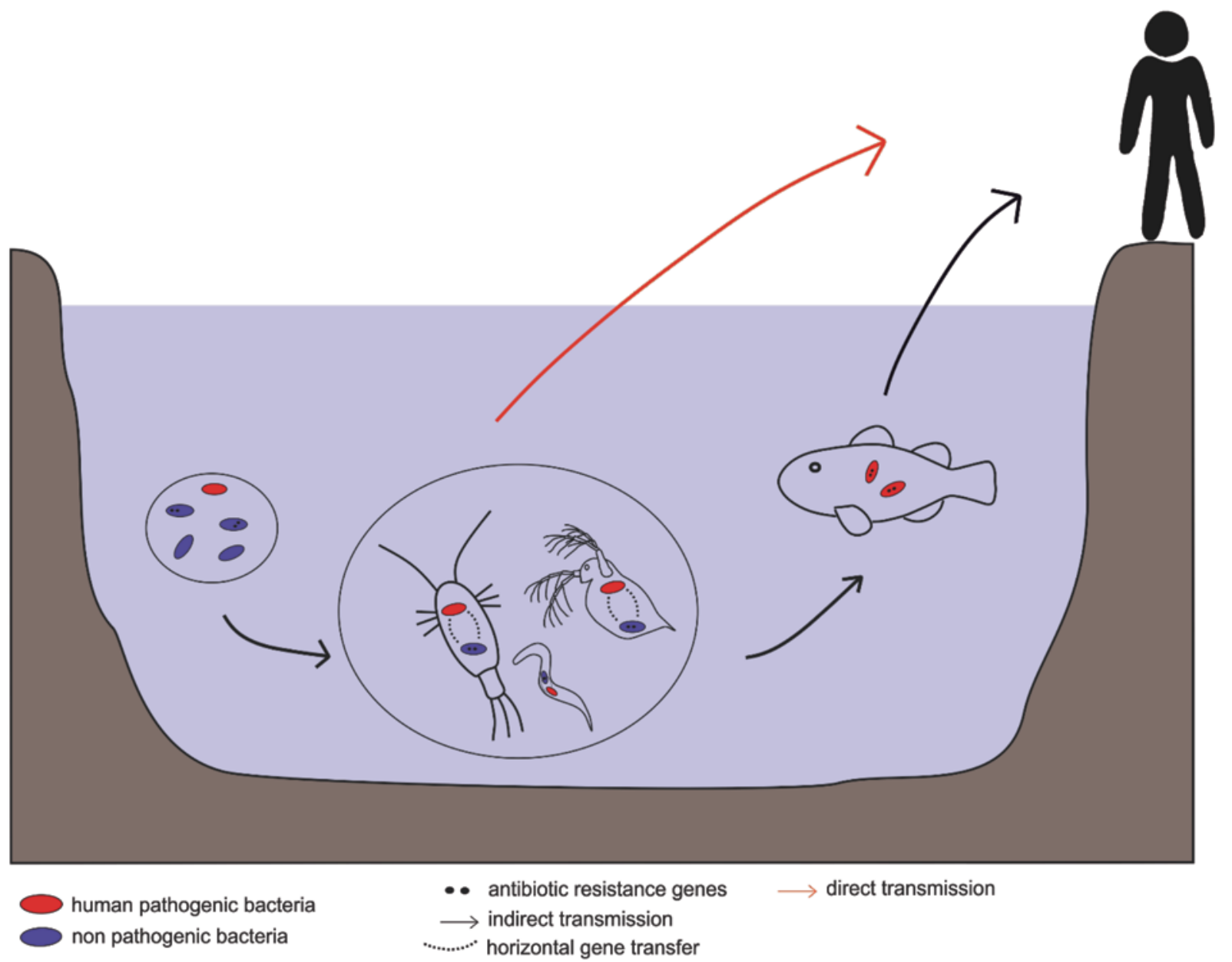

Fig. 1. Spread of ARGs within the meiofauna microbiome and along the food web. In meiofauna, ARGs could be transferred via horizontal gene transfer from non-pathogenic to pathogenic bacteria and their load magnified in the different hosts, potentially reaching humans (indirect transmission). In other cases, bathing activities, water consumption, and even inhalation of meiofauna can act as a direct transmission route. 
reach people directly through bathing activities (Martinez et al., 2020), and even through the drinking water (when not properly treated) (Kos et al., 2020) or the inhalation of suspended animals transported by the wind (Ptatscheck et al., 2018; Fontaneto, 2019), offering further routes to the spread of resistances (Fig. 1).

\section{Temperature effect on meiofauna resistome}

Water temperature could drive the accumulation of ARGs in meiofauna microbiome. In particular, the scenarios of climate change and rising temperatures are closely linked with bacterial processes and infections, increased horizontal gene transfer and overall bacterial growth rates (Philipsborn et al., 2016; reviewed in Burnham, 2021). Higher temperature was shown to lead to an increase in ARG abundances in the microbiome of freshwater meiofauna (Ding et al., 2021; Xue et al., 2021), probably due to the proliferation of ARB within these animals, even if some ARB seemed to be constitutively associated to them (e.g., Aeromonas strains in chironomid eggs) (Beaz-Hidalgo et al., 2012).

\section{Biomonitoring of antibiotic resistance in environment}

Meiofauna have been widely used as a proxy of water quality and some species have been the object of research for their resistance (or susceptibility) to the environmental pollution and potential implication in ecotoxicology (Schratzberger and Warwick, 1999; Alves et al., 2013). Recently, Zeppilli and colleagues (2015) reviewed the relevance of the meiofauna as a good bioindicator for anthropogenic impact. In addition to this, it would be interesting and useful to investigate the application of meiofauna in the biomonitoring of antibiotic polluted areas, since, as demonstrated, they could rapidly respond to such anthropogenic impact with a changing of the ARGs load and assemblage (Xue et al., 2021). Furthermore, the investigation of the meiofauna-hosted antibiotic resistome and pathobiome response in the scenario of climate change would be of great interest and the comparison of the antibiotic resistome and pathobiome of differentially tolerant meiofaunal species, along a gradient of anthropogenic impact, could help predicting ARGs enrichment in aquatic environments. 'Omics'-based approaches have been newly developed to test the health risk of ARGs and rely on the entire metagenome of the microbial communities to be assessed (e.g., Oh et al., 2018; de Nies et al., 2021). Such methods could be used to test a range of meiofaunal taxa as bioindicators for antibiotic resistance pollution.

\section{CONCLUSIONS}

The data collected and analyzed in this review highlight the potential role of meiofauna as reservoirs of antibiotic resistances in freshwater. In summary:
- Human and animal potential pathogens were part of the microbiome of freshwater meiofauna;

- ARGs were found in Chironomidae, Cladocera, Copepoda and Rotifera microbiome;

- the genes tet A and sul2 were retrieved in multiple reviewed studies (however this might be biased by the detection method used).

The few studies found claim for a further effort from the scientific community to fill the current knowledge gaps. Possible directions for future research could be:

- the investigation of unstudied taxa;

- the study of the interactions between meiofauna and environmental factors, e.g., temperature in the scenario of climate change;

- the study of the flexibility of the meiofauna microbiome and the horizontal gene transfer of ARGs using metagenomic approaches;

- the investigation of meiofauna microbiome as a bioindicator for antibiotic resistance in aquatic enviroments.

\section{ACKNOWLEDGEMENTS}

We want to thank Dr. Diego Fontaneto and Dr. Ester M. Eckert for their help in the topic. This work was supported by the WARFARE project (grant $\mathrm{n}^{\circ}$ 2018-0995) funded by Cariplo Foundation and by the "INDAGINI LIMNOLOGICHE SUL LAGO MAGGIORE” program funded by the International Commission for the Protection of Italian-Swiss Waters (CIPAIS).

\section{REFERENCES}

Adámek Z, Maršálek B, 2013. Bioturbation of sediments by benthic macroinvertebrates and fish and its implication for pond ecosystems: a review. Aquacult. Int. 21:1-17.

Akbar S, Gu L, Sun Y, Zhou Q, Zhang L, Lyu K, Huang Y, Yang $Z, 2020$. Changes in the life history traits of Daphnia magna are associated with the gut microbiota composition shaped by diet and antibiotics. Sci. Total Environ. 705:135827.

Allgaier M, Grossart H-P, 2006. Seasonal dynamics and phylogenetic diversity of free-living and particle-associated bacterial communities in four lakes in northeastern Germany. Aquat. Microb. Ecol. 45:115-128.

Alonso C, Pernthaler J, 2005. Incorporation of glucose under anoxic conditions by bacterioplankton from coastal North Sea surface waters. Appl. Environ. Microbiol. 71:1709-1716.

Alperi A, Figueras MJ, 2010. Human isolates of Aeromonas possess Shiga toxin genes (stx1 and stx2) highly similar to the most virulent gene variants of Escherichia coli. Clin. Microbiol. Infect. 16:1563-1567.

Alves AS, Adão H, Ferrero TJ, Marques JC, Costa MJ, Patrício $\mathrm{J}$, 2013. Benthic meiofauna as indicator of ecological changes in estuarine ecosystems: The use of nematodes in ecological quality assessment. Ecol. Indic. 24:462-475. 
Bass D, Stentiford GD, Wang H-C, Koskella B, Tyler CR, 2019. The pathobiome in animal and plant diseases. Trends Ecol. Evol. 34:996-1008.

Basu A, Hazra N, Ghosh K, 2010. Bioindicator potentiality of the chironomine larvae (Diptera: Chironomidae) for determination of antibiotic resistant microbial load of the aquatic ecosystem. Proc. Zool. Soc. 63:79-86.

Beaz-Hidalgo R, Shakèd T, Laviad S, Halpern M, Figueras MJ, 2012. Chironomid egg masses harbour the clinical species Aeromonas taiwanensis and Aeromonas sanarellii. FEMS Microbiol. Lett. 337:48-54.

Bergan T, 1981. Human- and animal-pathogenic members of the genus Pseudomonas, p. 666-700. In: M.P. Starr, H. Stolp, H.G. Trüper, A. Balows and H.G. Schlegel (eds.), The Prokaryotes. Cham, Springer.

Besser TE, Goldoft M, Pritchett LC, Khakhria R, Hancock DD, Rice DH, Gay JM, Johnson W, Gay CC, 2000. Multiresistant Salmonella Typhimurium DT104 infections of humans and domestic animals in the Pacific Northwest of the United States. Epidemiol. Infect. 124:193-200.

Bonaglia S, Nascimento FJA, Bartoli M, Klawonn I, Brüchert $\mathrm{V}, 2014$. Meiofauna increases bacterial denitrification in marine sediments. Nat. Commun. 5:5133.

Burnham JP, 2021. Climate change and antibiotic resistance: a deadly combination. Ther. Adv. Infect. Dis. 8:1-7.

Callens M, De Meester L, Muylaert K, Mukherjee S, Decaestecker E, 2020. The bacterioplankton community composition and a host genotype dependent occurrence of taxa shape the Daphnia magna gut bacterial community. FEMS Microbiol. Ecol. 96:fiaa128.

Callens M, Watanabe H, Kato Y, Miura J, Decaestecker E, 2018. Microbiota inoculum composition affects holobiont assembly and host growth in Daphnia. Microbiome 6:56.

Chaix G, Roger F, Berthe T, Lamy B, Jumas-Bilak E, Lafite R, Forget-Leray J, Petit F, 2017. Distinct Aeromonas populations in water column and associated with copepods from estuarine environment (Seine, France). Front. Microbiol. 8:1259.

Chao H, Kong L, Zhang H, Sun M, Ye M, Huang D, Zhang Z, Sun D, Zhang S, Yuan Y, Liu M, Hu F, et al., 2019. Metaphire guillelmi gut as hospitable micro-environment for the potential transmission of antibiotic resistance genes. Sci. Total Environ. 669:353-361.

Cooper RO, Cressler CE, 2020. Characterization of key bacterial species in the Daphnia magna microbiota using shotgun metagenomics. Sci. Rep. 10:652.

Cooper RO, Vavra JM, Cressler CE, 2021. Targeted manipulation of abundant and rare taxa in the Daphnia magna microbiota with antibiotics impacts host fitness differentially. Msystems 6:e00916-20.

Dallaire-Dufresne S, Tanaka KH, Trudel MV, Lafaille A, Charette SJ, 2014. Virulence, genomic features, and plasticity of Aeromonas salmonicida subsp. salmonicida, the causative agent of fish furunculosis. Vet. Microbiol. 169:1-7.

David LA, Maurice CF, Carmody RN, Gootenberg DB, Button JE, Wolfe BE, Ling AV, Devlin AS, Varma Y, Fischbach MA, Biddinger SB, Dutton RJ, et al., 2014. Diet rapidly and reproducibly alters the human gut microbiome. Nature 505:559-563.

de Kraker MEA, Stewardson AJ, Harbarth S, 2016. Will 10 mil- lion people die a year due to antimicrobial resistance by 2050? PLoS Med. 13:e1002184.

de Nies L, Lopes S, Busi SB, Galata V, Heintz-Buschart A, Laczny CC, May P, Wilmes P, 2021. PathoFact: a pipeline for the prediction of virulence factors and antimicrobial resistance genes in metagenomic data. Microbiome 9:49.

Di Cesare A, Eckert EM, Cottin C, Bouchez A, Callieri C, Cortesini M, Lami A, Corno G, 2020. The vertical distribution of tetA and intI1 in a deep lake is rather due to sedimentation than to resuspension. FEMS Microbiol. Ecol. 96:fiaa002.

Di Cesare A, Eckert EM, Teruggi A, Fontaneto D, Bertoni R, Callieri C, Corno G, 2015. Constitutive presence of antibiotic resistance genes within the bacterial community of a large subalpine lake. Mol. Ecol. 24:3888-3900.

Ding C, Ma J, Jiang W, Zhao H, Shi M, Cui G, Yan T, Wang Q, Li J, Qiu Z, 2021. Chironomidae larvae: A neglected enricher of antibiotic resistance genes in the food chain of freshwater environments. Environ. Pollut. 285:117486.

Dumont H, Negrea S, 2002. Introduction to the class Branchiopoda. In: Guides to the Identification of the Microinvertebrates of the Continental Waters of the World. Leiden, Backhuys Publ.

Ebert D, 2005. Ecology, epidemiology and evolution of parasitism in Daphnia. Bethesda: National Library of Medicine (US), National Center for Biotechnology Information.

Eckert EM, Amalfitano S, Di Cesare A, Manzari C, Corno G, Fontaneto D, 2020. Different substrates within a lake harbour connected but specialised microbial communities. Hydrobiologia 847:1689-1704.

Eckert EM, Anicic N, Fontaneto D, 2021. Freshwater zooplankton microbiome composition is highly flexible and strongly influenced by the environment. Mol. Ecol. 30:1545-1558.

Eckert EM, Di Cesare A, Stenzel B, Fontaneto D, Corno G, 2016. Daphnia as a refuge for an antibiotic resistance gene in an experimental freshwater community. Sci. Total Environ. 571:77-81.

Eckert EM, Pernthaler J, 2014. Bacterial epibionts of Daphnia: a potential route for the transfer of dissolved organic carbon in freshwater food webs. ISME J. 8:1808-1819.

Fenchel TM, 1978. The ecology of micro-and meiobenthos. Annu. Rev. Ecol. Syst. 9:99-121.

Finley RL, Collignon P, Larsson DGJ, McEwen SA, Li X-Z, Gaze WH, Reid-Smith R, Timinouni M, Graham DW, Topp E, 2013. The scourge of antibiotic resistance: The important role of the environment. Clin. Infect. Dis. 57:704-710.

Fonseca G, Fontaneto D, Di Domenico M, 2018. Addressing biodiversity shortfalls in meiofauna. J. Exp. Mari. Biol. Ecol. 502:26-38.

Fontaneto D, 2019. Long-distance passive dispersal in microscopic aquatic animals. Mov. Ecol. 7:10.

Fontaneto D, Flot J-F, Tang CQ, 2015. Guidelines for DNA taxonomy, with a focus on the meiofauna. Mar. Biodiv. 45:433-451.

Foster JA, McVey Neufeld K-A, 2013. Gut-brain axis: how the microbiome influences anxiety and depression. Trends Neurosci. 36:305-312.

Frankel-Bricker J, Song MJ, Benner MJ, Schaack S, 2020. Variation in the microbiota associated with Daphnia magna across genotypes, populations, and temperature. Microb. Ecol. 79:731-742. 
Freese HM, Schink B, 2011. Composition and stability of the microbial community inside the digestive tract of the aquatic crustacean Daphnia magna. Microb. Ecol. 4:882-894.

Fu J, Yang D, Jin M, Liu W, Zhao X, Li C, Zhao T, Wang J, Gao Z, Shen Z, Qiu Z, Li J-W, 2017. Aquatic animals promote antibiotic resistance gene dissemination in water via conjugation: Role of different regions within the zebra fish intestinal tract, and impact on fish intestinal microbiota. Mol. Ecol. 26:5318-5333.

Garner E, Benitez R, Wagoner E von, Sawyer R, Schaberg E, Hession WC, Krometis L-AH, Badgley BD, Pruden A, 2017. Stormwater loadings of antibiotic resistance genes in an urban stream. Water Res. 123:144-152.

Giere O, 2009. Meiobenthology: The microscopic motile fauna of aquatic sediments. Cham, Springer: 548 pp:

Grossart H-P, Dziallas C, Leunert F, Tang KW, 2010. Bacteria dispersal by hitchhiking on zooplankton. P. Natl. Acad. Sci. USA 107:11959-11964.

Grossart H-P, Dziallas C, Tang KW, 2009. Bacterial diversity associated with freshwater zooplankton. Environ. Microbiol. Rep. 1:50-55.

Guardabassi L, Butaye P, Dockrell DH, Fitzgerald JR, Kuijper EJ, ESCMID Study Group for Veterinary Microbiology (ESGVM), 2020. One Health: a multifaceted concept combining diverse approaches to prevent and control antimicrobial resistance. Clin. Microbiol. Infect. 26:1604-1605.

Halpern M, Senderovich Y, 2015. Chironomid microbiome. Microb. Ecol. 70:1-8.

Halpern M, Senderovich Y, Snir S, 2007. Rheinheimera chironomi sp. nov., isolated from a chironomid (Diptera; Chironomidae) egg mass. Int. J. Syst. Evol. Microbiol. 57:1872-1875.

Hamidou Soumana I, Linz B, Harvill ET, 2017. Environmental origin of the genus Bordetella. Front. Microbiol. 8:28.

Herrera LM, García-Laviña CX, Marizcurrena JJ, Volonterio O, León RP de, Castro-Sowinski S, 2017. Hydrolytic enzymeproducing microbes in the Antarctic oligochaete Grania sp. (Annelida). Polar Biol. 40:947-953.

Higgins RP, Thiel H, 1988. Introduction to the study of meiofauna. Washington DC, Smithsonian Institution Press: 488 pp.

Hong B, Ba Y, Niu L, Lou F, Zhang Z, Liu H, Pan Y, Zhao Y, 2018. A comprehensive research on antibiotic resistance genes in microbiota of aquatic animals. Front. Microbiol. 9:1617.

Horppila J, Ruuhijarvi J, Rask M, Karppinen C, Nyberg K, Olin $\mathrm{M}, 2000$. Seasonal changes in the diets and relative abundances of perch and roach in the littoral and pelagic zones of a large lake. J. Fish Biol. 56:51-72.

Howard A, O'Donoghue M, Feeney A, Sleator RD, 2012. Acinetobacter baumannii: An emerging opportunistic pathogen. Virulence 3:243-250.

Hurtado L, Miranda CD, Rojas R, Godoy FA, Añazco MA, Romero J, 2020. Live feeds used in the larval culture of red cusk eel, Genypterus chilensis, carry high levels of antimicrobial-resistant bacteria and antibiotic-resistance genes (ARGs). Animals 10:505.

Janda JM, Abbott SL, 2010. The genus Aeromonas: Taxonomy, pathogenicity, and infection. Clin. Microbiol. Rev. 23:35-73.

Jarett J, Fiore C, Mazel C, Lesser M, 2013. Fluorescent epibiotic microbial community on the carapace of a Bahamian ostracod. Arch. Microbiol. 195:595-604.

Jia J, Cheng M, Xue X, Guan Y, Wang Z, 2020. Characterization of tetracycline effects on microbial community, antibiotic resistance genes and antibiotic resistance of Aeromonas spp. in gut of goldfish Carassius auratus Linnaeus. Ecotoxicol. Environ. Saf. 191:110182.

Jia J, Guan Y, Cheng M, Chen H, He J, Wang S, Wang Z, 2018. Occurrence and distribution of antibiotics and antibiotic resistance genes in Ba River, China. Sci. Total Environ. 642:1136-1144.

Kalatzis PG, Bastías R, Kokkari C, Katharios P, 2016. Isolation and characterization of two lytic bacteriophages, $\varphi \mathrm{St} 2$ and $\varphi \mathrm{Grn} 1$; Phage therapy application for biological control of Vibrio alginolyticus in aquaculture live feeds. PLoS One 11:e0151101.

Kathol M, Fischer H, Weitere M, 2011. Contribution of biofilmdwelling consumers to pelagic-benthic coupling in a large river: Pelagic-benthic coupling by biofilms. Freshwater Biol. 56:1160-1172.

Kornijów R, 1997. The impact of predation by perch on the sizestructure of Chironomus larvae - the role of vertical distribution of the prey in the bottom sediments, and habitat complexity, p. 207-213 In: L. Kufel, A. Prejs and J.I. Rybak (eds.), Shallow lakes '95: Trophic cascades in shallow freshwater and brackish lakes. Dordrecht, Springer.

Kos J, Brmež M, Markić M, Sipos L, 2020. The mortality of nematodes in drinking water in the presence of ozone, chlorine dioxide, and chlorine. Ozone-Sci. Eng. 42:120-127.

Laviad S, Halpern M, 2016. Chironomids' Relationship with Aeromonas Species. Front. Microbiol. 7:

Leonard AFC, Zhang L, Balfour AJ, Garside R, Hawkey PM, Murray AK, Ukoumunne OC, Gaze WH, 2018. Exposure to and colonisation by antibiotic-resistant E. coli in UK coastal water users: Environmental surveillance, exposure assessment, and epidemiological study (Beach Bum Survey). Environ. Int. 114:326-333.

Loch TP, Faisal M, 2015. Emerging flavobacterial infections in fish: A review. J. Adv. Res. 6:283-300.

Macke E, Callens M, De Meester L, Decaestecker E, 2017. Host-genotype dependent gut microbiota drives zooplankton tolerance to toxic cyanobacteria. Nat. Commun. 8:1608.

MacLean RC, Millan AS, 2019. The evolution of antibiotic resistance. Science 365:1082-1083.

Majdi N, Schmid-Araya JM, Traunspurger W, 2020. Preface: Patterns and processes of meiofauna in freshwater ecosystems. Hydrobiologia 847:2587-2595.

Majdi N, Threis I, Traunspurger W, 2017. It's the little things that count: Meiofaunal density and production in the sediment of two headwater streams. Limnol. Oceanogr. 62:151-163.

Marchesi JR, Ravel J, 2015. The vocabulary of microbiome research: a proposal. Microbiome 3:31.

Marti E, Variatza E, Balcazar JL, 2014. The role of aquatic ecosystems as reservoirs of antibiotic resistance. Trends Microbiol. 22:36-41.

Martins MJF, Vandekerkhove J, Mezquita F, Schmit O, Rueda J, Rossetti G, Namiotko T, 2009. Dynamics of sexual and parthenogenetic populations of Eucypris virens (Crustacea: Ostracoda) in three temporary ponds. Hydrobiologia 636:219-232.

Martínez A, Eckert EM, Artois T, Careddu G, Casu M, Curini Galletti M, Gazale V, Gobert S, Ivanenko VN, Jondelius U, Marzano M, Pesole G, Zanello A, Todaro MA, Fontaneto D, 
2020. Human access impacts biodiversity of microscopic animals in sandy beaches. Commun. Biol. 3:175.

Moore BC, Martinez E, Gay JM, Rice DH, 2003. Survival of Salmonella enterica in freshwater and sediments and transmission by the aquatic midge Chironomus tentans (Chironomidae: Diptera). Appl. Environ. Microbiol. 69:4556-4560.

Mughini-Gras L, Dorado-García A, Duijkeren E van, Bunt G van den, Dierikx CM, Bonten MJM, Bootsma MCJ, Schmitt H, Hald T, Evers EG, Koeijer A de, Pelt W van, et al., 2019. Attributable sources of community-acquired carriage of $E s$ cherichia coli containing $\beta$-lactam antibiotic resistance genes: a population-based modelling study. Lancet Planet. Health 3:e357-e369.

Näslund J, Nascimento FJ, Gunnarsson JS, 2010. Meiofauna reduces bacterial mineralization of naphthalene in marine sediment. ISME J. 4:1421-1430.

Nasri A, Allouche M, Hannachi A, Harrath AH, Aldahmash W, Alwasel S, Mahmoudi E, Beyrem H, Boufahja F, 2020. Restructuring of a meiobenthic assemblage after sediment contamination with an antibacterial compound: Case study of ciprofloxacin. Ecotoxicol. Environ. Saf. 205:111084.

Nematollahi A, Decostere A, Pasmans F, Haesebrouck F, 2003. Flavobacterium psychrophilum infections in salmonid fish. J. Fish Dis. 26:563-574.

Neuenschwander SM, Pernthaler J, Posch T, Salcher MM, 2015. Seasonal growth potential of rare lake water bacteria suggest their disproportional contribution to carbon fluxes. Environ. Microbiol. 17:781-795.

Nnadozie CF, Odume ON, 2019. Freshwater environments as reservoirs of antibiotic resistant bacteria and their role in the dissemination of antibiotic resistance genes. Environ. Pollut. 254:113067.

Oh M, Pruden A, Chen C, Heath LS, Xia K, Zhang L, 2018. MetaCompare: a computational pipeline for prioritizing environmental resistome risk. FEMS Microbiol. Ecol. 94:fiy079.

Olanrewaju TO, McCarron M, Dooley JSG, Arnscheidt J, 2019. Transfer of antibiotic resistance genes between Enterococcus faecalis strains in filter feeding zooplankton Daphnia magna and Daphnia pulex. Sci. Total Environ. 659:1168-1175.

Olmo C, Armengol X, Antón-Pardo M, Ortells R, 2016. The environmental and zooplankton community changes in restored ponds over 4 years. J. Plankton Res. 38:490-501.

Olszewski P, Bruhn-Olszewska B, Namiotko L, Sell J, Namiotko T, 2020. Co-cultured non-marine ostracods from a temporary wetland harbor host-specific microbiota of different metabolic profiles. Hydrobiologia 847:2503-2519.

O’Neill J, 2014. Antimicrobial resistance. Tackling a crisis for the health and wealth of nations.

Peerakietkhajorn S, Kato Y, Kasalický V, Matsuura T, Watanabe H, 2016. Betaproteobacteria Limnohabitans strains increase fecundity in the crustacean Daphnia magna: symbiotic relationship between major bacterioplankton and zooplankton in freshwater ecosystem. Environ. Microbiol. 18:2366-2374.

Philipsborn R, Ahmed SM, Brosi BJ, Levy K, 2016. Climatic drivers of diarrheagenic Escherichia coli incidence: A systematic review and meta-analysis. J. Infect. Dis. 214:6-15.

Pinto TK, Austen MCV, Warwick RM, Somerfield PJ, Esteves AM, Castro FJV, Fonseca-Genevois VG, Santos PJP, 2013. Nematode diversity in different microhabitats in a mangrove region. Mar. Ecol. 34:257-268.
Prather CM, Pelini SL, Laws A, Rivest E, Woltz M, Bloch CP, Toro ID, Ho C-K, Kominoski J, Newbold TAS, Parsons S, Joern A, 2013. Invertebrates, ecosystem services and climate change. Biol. Rev. 88:327-348.

Preiswerk D, Walser J-C, Ebert D, 2018. Temporal dynamics of microbiota before and after host death. ISME J. 12:2076-2085.

Ptatscheck C, Gehner S, Traunspurger W, 2020. Should we redefine meiofaunal organisms? The impact of mesh size on collection of meiofauna with special regard to nematodes. Aquat. Ecol. 54:1135-1143.

Ptatscheck C, Gansfort B, Traunspurger W, 2018. The extent of wind-mediated dispersal of small metazoans, focusing nematodes. Sci. Rep. 8:6814

Pund RP, Theegarten D, 2008. [The importance of aeromonads as a human pathogen].[Article in German]. Bundesgesundheitsblatt Gesundheitsforschung Gesundheitsschutz 51:569-576.

Qi W, Nong G, Preston JF, Ben-Ami F, Ebert D, 2009. Comparative metagenomics of Daphnia symbionts. BMC Genomics 10:172.

Quinlan EL, Nietch CT, Blocksom K, Lazorchak JM, Batt AL, Griffiths R, Klemm DJ, 2011. temporal Dynamics of Periphyton Exposed to Tetracycline in Stream Mesocosms. Environ. Sci. Technol. 45:10684-10690.

Rhee SH, Pothoulakis C, Mayer EA, 2009. Principles and clinical implications of the brain-gut-enteric microbiota axis. Nat. Rev. Gastroenterol. Hepatol. 6:306-314.

Robinson TP, Bu DP, Carrique-Mas J, Fèvre EM, Gilbert M, Grace D, Hay SI, Jiwakanon J, Kakkar M, Kariuki S, Laxminarayan R, Lubroth J, Magnusson U, Thi Ngoc P, Van Boeckel TP, Woolhousep MEJ, 2016. Antibiotic resistance is the quintessential One Health issue. Trans. R. Soc. Trop. Med. Hyg. 110:377-380.

Rossi V, Albini D, Benassi G, Menozzi P, 2012. To rest in hydration: Hatching phenology of resting eggs of Heterocypris incongruens (Crustacea: Ostracoda). Fund. Appl. Limnol. 181:49-58.

Sahandi J, Sorgeloos P, Xiao H, Wang X, Qi Z, Zheng Y, Tang $X, 2019$. The use of selected bacteria and yeasts to control Vibrio spp. in live food. Antibiotics 8:95.

Sathicq MB, Sabatino R, Corno G, Di Cesare A, 2021. Are microplastic particles a hotspot for the spread and the persistence of antibiotic resistance in aquatic systems? Environ. Pollut. 279:116896.

Schmid PE, Tokeshi M, Schmid-Araya JM, 2000. Relation between population density and body size in stream communities. Science 289:1557-1560.

Schmid-Araya JM, Schmid PE, Majdi N, Traunspurger W, 2020. Biomass and production of freshwater meiofauna: a review and a new allometric model. Hydrobiologia 847:2681-2703.

Schratzberger M, Ingels J, 2018. Meiofauna matters: The roles of meiofauna in benthic ecosystems. J. Exp. Mar. Biol. Ecol. 502:12-25.

Schmid-Araya JM, Schmid PE, 2000. Trophic relationships: integrating meiofauna into a realistic benthic food web. Freshwater Biol. 44:149-163.

Schön I, Kamiya T, Van den Berghe T, Van den Broecke L, Martens K, 2019. Novel Cardinium strains in non-marine ostracod (Crustacea) hosts from natural populations. Mol. Phylogenet. Evol. 130:406-415.

Schratzberger M, Somerfield PJ, 2020. Effects of widespread 
human disturbances in the marine environment suggest a new agenda for meiofauna research is needed. Sci. Total Environ. 728:138435.

Schratzberger M, Ingels J, 2018. Meiofauna matters: The roles of meiofauna in benthic ecosystems. J. Exp. Mar. Biol. Ecol. 502:12-25.

Schratzberger M, Warwick RM, 1999. Differential effects of various types of disturbances on the structure of nematode assemblages: an experimental approach. Marine Ecology Progress Series 181:227-236.

Senderovich Y, Gershtein Y, Halewa E, Halpern M, 2008. Vibrio cholerae and Aeromonas: do they share a mutual host? ISME J. 2:276-283.

Sharon G, Segal D, Ringo JM, Hefetz A, Zilber-Rosenberg I, Rosenberg E, 2010. Commensal bacteria play a role in mating preference of Drosophila melanogaster. Proc. Natl. Acad. Sci. 107:20051-20056.

Shin SC, Kim S-H, You H, Kim B, Kim AC, Lee K-A, Yoon JH, Ryu J-H, Lee W-J, 2011. Drosophila Microbiome Modulates Host Developmental and Metabolic Homeostasis via Insulin Signaling. Science 334:670-674.

Sison-Mangus MP, Mushegian AA, Ebert D, 2015. Water fleas require microbiota for survival, growth and reproduction. ISME J. 9:59-67.

Sommer F, Bäckhed F, 2013. The gut microbiota - masters of host development and physiology. Nat. Rev. Microbiol. 11:227-238

Stead TK, Schmid-Araya JM, Hildrew AG, 2005. Secondary production of a stream metazoan community: Does the meiofauna make a difference? Limnol. Oceanogr. 50:398-403.

Stratev D, Odeyemi OA, 2016. Antimicrobial resistance of Aeromonas hydrophila isolated from different food sources: A mini-review. Journal of Infection and Public Health 9:535-544.

Suzuki S, Pruden A, Virta M, Zhang T, 2017. Editorial: Antibiotic resistance in aquatic systems. Front. Microbiol. 8:14.

Syrova E, Kohoutova L, Dolejska M, Papezikova I, Kutilova I, Cizek A, Navratil S, Minarova H, Palikova M, 2018. Antibiotic resistance and virulence factors in mesophilic Aeromonas spp. from Czech carp fisheries. J. Appl. Microbiol. 125:1702-1713.
Tang K, 2005. Copepods as microbial hotspots in the ocean: effects of host feeding activities on attached bacteria. Aquat. Microb. Ecol. 38:31-40.

Tang K, Turk V, Grossart H, 2010. Linkage between crustacean zooplankton and aquatic bacteria. Aquat. Microb. Ecol. 61:261-277.

Tang KW, Dziallas C, Grossart H-P, 2011. Zooplankton and aggregates as refuge for aquatic bacteria: protection from UV, heat and ozone stresses used for water treatment. Environ. Microbiol. 13:378-390.

Traunspurger W, Majdi N, 2017. Meiofauna, p. 273-295 In: F. Hauer and G. Lamberti (eds.), Methods in Stream Ecology. Amsterdam, Elsevier.

Turnbaugh PJ, Ley RE, Mahowald MA, Magrini V, Mardis ER, Gordon JI, 2006. An obesity-associated gut microbiome with increased capacity for energy harvest. Nature 444:1027-1031.

Vandekerkhove J, Martens K, Rossetti G, Mesquita-Joanes F, Namiotko T, 2013. Extreme tolerance to environmental stress of sexual and parthenogenetic resting eggs of Eucypris virens (Crustacea, Ostracoda). Freshwater Biol. 58:237-247.

Vayssier-Taussat M, Albina E, Citti C, Cosson JF, Jacques MA, Lebrun MH, Le Loir Y, Ogliastro M, Petit MA, Roumagnac $\mathrm{P}$, Candresse T, 2014. Shifting the paradigm from pathogens to pathobiome: new concepts in the light of meta-omics. Front. Cell Infect. Microbiol. 5:4-29.

Waldor MK, Tyson G, Borenstein E, Ochman H, Moeller A, Finlay BB, Kong HH, Gordon JI, Nelson KE, Dabbagh K, Smith H, 2015. Where Next for Microbiome Research? PLoS Biol. 13:e1002050.

Xue X, Wang L, Xing H, Zhao Y, Li X, Wang G, Wang Z, 2021. Characteristics of phytoplankton-zooplankton communities and the roles in the transmission of antibiotic resistance genes under the pressure of river contamination. Sci. Total Environ. 780:146452.

Zeppilli D, Sarrazin J, Leduc D, Arbizu PM, Fontaneto D, Fontanier C, Gooday AJ, Kristensen RM, Ivanenko VN, Sørensen MV, Vanreusel A, Thébault J, et al., 2015. Is the meiofauna a good indicator for climate change and anthropogenic impacts? Mar. Biodivers. 45:505-535. 